\title{
OD INSTITUCIJE
}

\section{UMETNOSTI DO DISPOZITIVA UMETNOSTI}

\section{Strategije institucionalne kritike}

\author{
FROM THE \\ INSTITUTION OFART TOTHE \\ APPARATUSOFART \\ Strategies of \\ Institutional Critique
}


PREGLEDNI RAD

Primljen: 30.1.2020.

Prihvaćen: 11.5.2020.

DOI: $10.31664 / z u .2020 .106 .06$

\section{REVIEW PAPER}

Received: January 30, 2020

Accepted: November 11, 2020

DOI: $10.31664 /$ zu.2020.106.06

\section{APSTRAKT}

Institucionalna kritika jedan je od ključnih fenomena u umetnosti druge polovine 20. veka. Polazište $u$ istraživanju je Buchlohova teza o prelazu sa industrijske estetike, estetike proizvodnje i potrošnje na estetiku administracije: problematizovanje institucija kao dominantnih referentnih tački u polju umetnosti. Glavno istraživačko pitanje je: $U$ čemu je značaj institucionalne kritike ako je ona institucionalno prihvaćen način delovanja? Da li je institucionalna kritika u funkciji institucija pružajući im legitimitet "otvorenosti" u smislu da mogućnost otpora postoji ili je u pitanju emancipatorska praksa? Teza rada je da je institucionalna kritika ukazala na ulogu institucija u načinu funkcionisanja umetničkog rada, čime je pitanje neutralnosti institucija kao dominantnog obeležja modernističke paradigme umetnosti dovedeno u pitanje. Istovremeno, odigrala je ključnu ulogu u konstituisanju kritičkog pristupa u umetnosti, u formulisanju stava kojim se dovode u pitanje postojeće institucionalne matrice i time učinila vidljivim, a ujedno i podložnim kritici, delovanje samih institucija.

\section{KLJUČNE REČI}

institucionalna kritika, institucija umetnosti, dispozitiv umetnosti, savremena umetnost, autonomija umetnosti, estetika administracije, muzej, tržište, teorija sistema
SUMMARY

Institutional critique is one of the key phenomena in the art of the second half of the 2othcentury. The starting point of research is Buchloh's thesis on the transition from industrial aesthetics, aesthetics of production and consumption to the aesthetics of administration: problematization of institutions as dominant reference points in the field of art. The main research question is: What is the significance of in stitutional critique if it is an institutionally accepted way of acting? Does institutional critique act in the service of institutions by giving them the legitimacy of "openness", in the sense that the possibility of resistance exists, or is it an emancipatory practice? The thesis of the paper is that institutional critique has indicated the role of institutions related to artwork, which brought into question the issue of the neutrality of institutions as a dominant feature of the modernist paradigm of art. At the same time, it has played a key role in constituting a critical approach to art, formulating an attitude that calls into question the existing institutional matrices, and thus made visible, and at the same time subject to criticism, the actions of the institutions themselves. The common denominator of different artistic strategies related to institutional critique is the problematization of artistic institutions as points of different confrontations of interest-economic, political, financial-which called into question the idea of autonomy as an ideological cover for various non-artistic interests. At the same time, this has shown that art does not function in binary code-art vs. non-art, which was the dominant logic of the 2othcentury modernist discourse and pure categories - but as an apparatus (dispositif): a field in which relations, powers and connections with different walks of life, artistic and non-artistic, intersect. This has simultaneously made institutional critique an inseparable part of contemporary art.

\section{KEYWORDS}

institutional critique, art institution, apparatus (dispositif), contemporary art, art autonomy, aesthetics of administration, museum, market, systems theory

\section{Maja Stanković}

Fakultet za medije i komunikacije, Univerzitet Singidunum, Beograd /

The Faculty of Media and Communications, Singidunum University, Belgrade. 
Institucionalna kritika je jedan od ključnih fenomena u umetnosti druge polovine 20. veka. Prvi talas institucionalne kritike dovodi se u vezu sa šezdesetim, drugi sa osamdesetim, a neki autori smatraju da se može govoriti i o trećem talasu institucionalne kritike posle 2000. Postoje brojne poteškoće u definisanju pojma institucionalne kritike. Jednim delom, one su proizvod upravo eluzivnog hronološkog okvira; zatim, nije sasvim izvesno ni kada je ovaj pojam počeo da se koristi, a velika je mogućnost da se pojavio u procesu institucionalizacije ovih umetničkih praksi. Takođe, upitno je i da li je institucionalna kritika isto što i kritika institucija, što je mnogo širi diskurzivni okvir ili se odnosi samo na određene umetničke prakse.

Zajedničko polazište za definisanje institucionalne kritike je: "umetnost koja razotkriva 'strukturu i logiku muzeja i galerija'”. ${ }^{1}$ Muzeji i galerije kao "najisturenije" institucije umetnosti bile su prve na udaru kritike. Istovremeno, iskustvo umetnosti 20. veka, pokazalo je da je njihova uloga mnogo kompleksnija, da prevazilazi fizičke granice prostora i konstitutivna je za sam umetnički rad. Ono što je, međutim, posebno indikativno za ovaj fenomen je preklapanje dva, naizgled, nespojiva procesa: uvođenje kritičkog diskursa u kojem su same institucije predmet kritike i njihova institucionalizacija, prihvatanje od strane samih institucija kao legitimne umetničke prakse, čime se nameću nekoliko pitanja: $\mathrm{U}$ čemu je značaj institucionalne kritike ako je ona institucionalno prihvaćen način delovanja? Da li je institucionalna kritika u funkciji samih institucija, jer im pruža legitimitet i obezbeđuje poželjnu auru "otvorenosti" ili emancipacijska praksa? Posebno pitanje je na koji način iskustvo institucionalne kritike funkcioniše danas, odnosno da li se i kako postojeći pojam može apgrejdovati u kontekstu umetnosti na početku 21. veka?

Čini se da je institucionalna kritika mnogo više od istorijske pojave, žanra ili pravca. I pored toga što se dovodi u vezu sa umetnicima kao što su Daniel Buren, Michael Asher, Hans Haacke, Robert Smithson i Marcel Broodthaers, moglo bi se reći da je u pitanju određeni kritički aparat, "analitička alatka, metod prostornog i političkog kriticizma ili artikulacije", ${ }^{2}$ koji se konstituiše od šezdesetih godina prošlog veka i prisutan je i danas. Ono što se, svakako, promenilo imajući u vidu prelaz od 20. u 21. vek, od moderne u savremenu umetnost kao i niz promena u svim registrima povezanih sa globalizacijom, ulaskom u digitalnu paradigmu i "fluidnu modernost" ${ }^{3}$ je, pre svega, način percepcije institucija. To se može dovesti u vezu sa prelazom od institucije umetnosti ka dispozitivu umetnosti, što je problemski okvir ovog rada.

$\rightarrow$

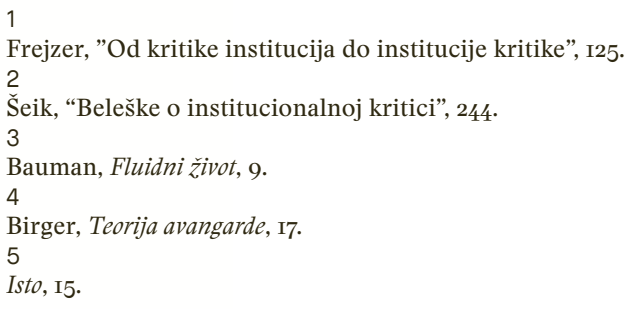
Šeik, "Beleške o institucionalnoj kritici”, 244 . Isto, $\mathrm{I} 5$. 2 3 4 5 


\section{INSTITUCIJA UMETNOSTI}

Jedno od polazišta u Teoriji avangarde je pojam institucija umetnosti, koji Bürger preuzima od Marcusea i objašnjava na sledeći način: "status koji kultura, izdvojena iz životne prakse, zadobija u građanskom društvu. Taj status (institucija umetnosti) predstavlja okvirne uslove unutar kojih se pojedinačna dela proizvode i percipiraju." ${ }^{4}$ Ovaj pojam dovodi u pitanje uvreženu fikciju da umetničko delo deluje pojedinačno: nasuprot tome, "delo deluje u okviru institucije umetnosti". ${ }^{5}$ Kao i sve druge institucije i ona je društvena tvorevina. Ono po čemu se razlikuje od drugih institucija je to što okvir njenog delovanja ne čini korpus određenih tekstova kao što je to slučaj sa zakonima u instituciji prava, već se oblikuje indirektno "preko refleksija autora i kritičara". Iz toga sledi da ono što prevlada kao dominantno shvatanje umetnosti, a što se odnosi na način produkcije i recepcije umetničkog dela, postaje okvir njenog delovanja. Institucija umetnosti se konstituiše unutar građanskog društva u 18. veku i jedno od njenih ključnih obeležja je autonomija. Za Bürgera je autonomija "opozicija prema životnoj praksi". Ipak, on naglašava da postoji dijalektički odnos između umetnosti i društva, jer i pored toga što je institucija umetnosti izvan životne prakse, umetnost je deo društva. Kako se onda može razumeti pojam autonomije?

Autonomija zamenjuje utilitarni način funkcionisanja, koji je obeležio tradicionalni sistem umetnosti u kojem su umetnička dela neodvojiva od ritualne ili reprezentativne funkcije. Nasuprot tome, u modernom sistemu umetnosti jedina funkcija umetničkog dela je estetska i ona je različita od svih ostalih delatnosti koje pripadaju društvenom registru. Avangarda je reakcija na ovakvo shvatanje umetnosti, čiji efekat prepoznaje kao distancu u odnosu na društvo koja izaziva krizu (u) umetnosti. To naročito dolazi do izražaja početkom Prvog svetskog rata: društvo koje zastupa humanističke ideale, estetske vrednosti i uzvišenost kao ultimativni umetnički doživljaj, istovremeno je pokretač nemilosrdne ratne mašine. Avangardno polazište je da umetnost mora da reflektuje ono što se događa u društvu. U protivnom, zatvara se u određeni tip manira, što je glavna zamerka institucionalnom shvatanju umetnosti. Avangarda se, samim tim, kritički odnosi ne prema samoj ideji autonomije, već prema zatvorenosti i inertnosti institucije umetnosti sa kojima se ideja autonomije izjednačava. Time se prvi put otvara pitanje odnosa između institucije i umetnosti.

Avangarda je eksces unutar institucije umetnosti, koji nije promenio način njenog rada niti dominantnu predstavu o umetnosti, ali je ostavio dugoročni trag. Na tom tragu formira se i institucionalna kritika, u periodu kada se javlja interesovanje za avangardu, što je u velikoj meri motivisano i događajima iz '68.: niz društveno-političkih događaja i socijalnih previranja imalo je zajedničko polazište, a to je, između ostalog, sumnja u postojeće institucije. Predmet sumnje je, opet, autonomija, ali je sada to sumnja u autonomiju institucija $u$ svim društvenim registrima. To najbolje ilustruje tekst jednog studentskog letka koji je kružio Parizom u maju 1968.: 
Odbijamo da postanemo učitelji koji služe mehanizmu društvene selekcije u obrazovnom sistemu koji deluje na račun dece iz radnicke klase, odbijamo da postanemo sociolozi koji izmisljaju slogane za vladine izborne kampanje, odbijamo da postanemo psiholozi zaduženi za organizovanje "timova radnika" koji "rade" u najboljem interesu svojih šefova, odbijamo da postanemo naučnici čija će istraživanja biti korišćena za ekskluzivne interese profitne ekonomije. ${ }^{6}$

Do '68. dominiralo je konvencionalno shvatanje institucija kao datosti i autoriteta koji uređuju odnose među ljudima i ne dovode se u pitanje. Iskustvo '68. pokazalo je da su za rad institucija ključne "ideološke matrice uređenja odnosa između ljudi nasleđene iz prošlosti koje nemaju puno dodirnih tačaka sa promenama koje se odigravaju u društvu".? Strategije institucionalne kritike konstituišu se na iskustvu '68. i problematizuju upravo tu ideološku komponentu autonomije kao modusa funkcionisanja institucija u umetnosti, pre svega, galerija i muzeja. Polazište je avangarda, te stoga Benjamin Buchloh pojavu institucionalne kritike dovodi u vezu sa trećim talasom recepcije avangarde i konceptualnom umetnošću. U okviru konceptualne umetnosti pojavljuje se tzv. estetika administracije, uvođenje birokratskih modela administriranja informacija i podataka, što su modeli preuzeti od institucija. Time se otvara prostor za konstituisanje institucionalne kritike kao umetničke prakse. ${ }^{8}$

Pojava institucionalne kritike se u širem kontekstu može dovesti u vezu i sa tzv. institucionalnom teorijom u kritičkoj misli Emila Durkheima, Maxa Webera i kasnije Seamusa Millera i Johna Searlea. Ipak, diskutabilno je uvođenje čvršćih relacija sa opštom istorijom institucionalne teorije koja se unazad može pratiti do tzv. ranog institucionalizma s kraja 19. veka koji nastaje u okviru "ekonomskih teorija, političkih nauka, sociologije, sociološke teorije i organizacionih studija”. ${ }^{9} \mathrm{Za}$ njeno nastajanje ključna je leva politička misao, koja je preko kritičke teorije frankfurtske škole filozofa kao što su Adorno, Benjamin, Marcuse i posebno Althusserove kritike ideoloških aparata, integrisana u kritički diskurs na liniji poststrukturalističkih čitanja. Simptomatično je da se kao zasebni fenomen prepoznaje mnogo kasnije u odnosu na umetničke prakse s kojima se dovodi u vezu. Prevagu umetničkih praksi u odnosu na institucionalne teorije u konstituisanju fenomena institucionalne kritike potvrđuje i zapažanje Davida Graebera, antropologa, aktiviste i levičara, koje iznosi u svom opsežnom istraživanju fenomena institucije i birokratije kao njenog pratećeg aparata.On ističe da u šezdesetim godinama prošlog veka, birokratija prestaje da biva predmet teorijskih i kritičkih analiza. Iz toga se može izvesti zanimljiv zaključak, a to je da su, u tom trenutku, jedino umetnici imali strategije za problematizovanje institucija.

Institucionalna kritika tematizuje institucionalni okvir unutar kojeg se izlažu umetnički radovi. Muzej je posebno značajan zbog svoje identitetske funkcije, sistema vrednosti koji reprezentuje i koji je odigrao ključnu ulogu u periodu rane moderne i formiranja nacionalnih identiteta baziranih na istorijskim i drugim narativima. Ono što definiše način njegovog funkcionisanja, a povezano je sa autonomijom kao ključnim obeležjem institucije umetnosti, je neutralni kontekst. To se prepoznaje u idejnom, ali i u vizuelnom i arhitektonskom planu: beli, neutralni prostor koji ima jedinstvenu namenu, reprezentovanje umetnosti. Efekat toga je i uspostavljanje jasnih granica u odnosu na neinstitucionalno, neumetničko i svakodnevno, što je još jedna od osobenosti institucije umetnosti. Institucionalno definisan okvir garantuje originalnost, autentičnost i jedinstvenost izloženim predmetima. Ta logika jasnih granica binarnog tipa prelama se kroz različite lejere unutar institucije umetnosti kao što su kategorizacije-umetnost vs. ne-umetnost, visoka vs. popularna umetnost, lepe i primenjene umetnosti-i podele: medijske, žanrovske i dr.

Logika jasnih granica između umetničkog, institucionalnog i neumetničkog i svakodnevnog predmet je analize u praksama institucionalne kritike. U prvom talasu, ključne strategije su odvajanje od muzeja kao institucionalnog okvira za funkcionisanje umetnosti: izlaganje u neumetničkim prostorima (napuštenim fabrikama, skladištima, prostorima neumetničke namene), kombinovanje izlagačke i neizlagačke funkcije (proizvođenje galerije u privatni prostor, bolnicu, tržnicu...), izlazak iz izlagačkog prostora u javni prostor, na ulicu i izlazak van grada, u prirodu, nenaseljeni prostor (Land art). Pokazalo se, međutim, da su načini delovanja institucija mnogo kompleksniji i da prevazilaze opipljiv fizički prostor. Dolazi do promena umetničkih strategija, što ujedno predstavlja ulazak u drugu fazu, odnosno novi talas institucionalne kritike. Jedan od radova koji direktno problematizuje ovaj prelaz je Burenov rad simptomatičnog naziva Photo-souvenir: Within and Beyond the Frame (John Weber Gallery, New York 1973.). I u svojim prethodnim intervencijama Buren dovodi u pitanje gotovo sve institucionalizovane vrednosti umetničkog dela kao estetskog, autonomnog, autentičnog i jedinstvenog predmeta. Ovim radom destabilizuje shvatanje po kojem se institucionalni okvir izjednačava sa fizičkim prostorom.

Ono što je takođe, doprinelo destabilizovanju shvatanja po kojem je institucija svedena na određeni fizički prostor su i promene koje se odigravaju u teorijskom registru. One su povezane sa nizom novih čitanja, čiji je efekat udaljavanje od strukturalizma kao dominantne metodološke paradigme tokom šezdesetih godina. Strukturalističko polazište je sistem kao samouređena struktura koja ima sopstvena pravila, što je kompatibilno sa modernističkim shvatanjem autonomije umetnosti bazirane na idejama autorefleksivnosti, samokritičnosti, samodovoljnosti i bezinteresnosti. ${ }^{10}$ Polazište za postrukturalističke pristupe je odustajanje od shvatanja autonomije kao zatvorenog sistema, samoregulativne strukture definisane unutar sopstvenih granica. Fuko uvodi pojam diskurs kojim dovodi u pitanje autonomnost i neutralnost znanja i povezuje ga sa odnosima moći.

U registru umetnosti su izlagačke institucije prepoznate kao ključne tačke moći, te je stoga način njihovog funkcionisanja u fokusu različitih umetničkih intervencija. Michael Asher u svom radu Pomona College Project (Gallery in Claremont, 
California, 1970.) menja izgled galerije (pravljenjem koridora unutar galerije, spuštanjem plafona i sl.), ali dovodi u pitanje i njenu izlagačku funkciju tako što ona sama postaje "umetnički rad". Istovremeno, ukazuje na njen artificijelni status, odnosno, artificijelni status institucija, uopšte. Tokom trajanja izložbe, uklonjena su vrata i ulaz je transformisan u pravougaoni otvor, tako da je galerija bila "izložena" dvadeset i četiri sata, što upućuje i na "mali socijalni eksperiment" u kojem se institucija, na potpuno novi-otvorennačin, povezuje sa okolinom i publikom. "Otvorenost" kao izmenjeni način rada galerije polazište je i u radu Untitled (Claire Copley Gallery, Los Angeles, 1974.) u kojem je, u stvari, izjednačena sa ogoljenošću, tako što su iz galerije uklonjeni svi pregradni zidovi koji dele izlagački od pomoćnih, kancelarijskih i higijenskih prostora. Time je, direktno izložena posmatraču, galerija kao složeni sistem, koji čine umetničke ali i neumetničke funkcije. Još jedan od nezaobilaznih istorijskih primera institucionalne kritike je rad Marcela Broodthaersa Musee d'Art Moderne, Department des Aigles (1972.). Umetnik se izmešta u poziciju moći, tako što pervertira ustaljeni muzejski model zasnovan na podelama između "onih koji proizvode i onih koji prezentuju umetnost, onih u čije ime se govori i onih koji govore". ${ }^{11}$ Rad Hansa Haackea Shapolsky et al. Manhattan Real Estate Holdings, a Real-Time Social System, as of May 1 (1971.) birokratski koncipiranog naziva i izgleda, sastavljen od fotografskih dokumenata i informacija, ishod je istraživanja koje ukazuje na "nevidljive" veze između različitih institucija, umetničkih i neumetničkih, kao i mrežu socijalnih, ekonomskih i političkih odnosa koji određuju funkcionisanje umetničkih institucija. Nešto slično, ali na sasvim drugačiji način, komičan i sarkastičan, pokazuje i Edinburška izjava Raše Todosijevića (1975.) koji kroz tekst, sasvim direktno i eksplicitno nabraja ljude, funkcije i relacije koje konstituišu umetnost u najrazličitijim lejerima. S druge strane, isti umetnik u sklopu serije Nijedan dan bez crte (1976./77.), takođe, vrlo direktno ukazuje na koji način kontekstualni, institucionalni ili neistitucionalni okvir u kojem se rad izlaže utiče na njegovu poziciju unutar sistema umetnosti: Jedna linija, in private i 200.000 linija za Pariski bijenale.

\section{DISPOZITIV UMETNOSTI}

6

Bois et al., Art Since 19oo, 40 [op. prev.].

7

Stimson, “What Was Institutional Critique?", 2I.

8

Institucionalna kritika se može posmatrati i šire tako što, pored umetničkih strategija, koje su predmet ove analize, uključuje i političko aktivistički rad umetnika i kritičara kao što su delovanje grupa The Art Workers' Coalition (AWC) i Guerilla Art Action Group (GAAG), što nije obuhvaćeno analizom u ovom tekstu. (prim.aut.)

Đorđević, Institucionalna kritika, I6.

10

Greenberg, "Modernističko slikarstvo", 34 .

11

Bois et al., Art Since 1900, 40.

12

Frejzer, "Od kritike institucija do institucije kritike", 224.
Andrea Fraser smatra da je institucionalna kritika, od svojih početaka, bila institucionlizovana, jer se odvijala unutar institucionalnih okvira. Ipak, kako navodi, momenat njene kooptacije od strane institucija nije toliko bitan, već ono što je promenila u načinu njihovog percipiranja. Prvo, proširila je "polje umetnosti" uvodeći u registar umetnosti prakse pomoću kojih se problematizuju različiti fizički i socijalni sistemi. I drugo, uvela je instituciju kritike u umetnost, čiji se počeci mogu pratiti unazad do avangardnih istraživanja. Pomak u percepciji umetničkih institucija, može se opisati jednom rečenicom: "Danas je nemoguće biti izvan." ${ }^{12}$ Izvan se odnosi na institucije. Izvan se odnosi na sve ono što čini konceptualni, perceptivni i distributivni aparat umetnosti, a pored izlagačkih, uključuje i sve druge institucije u registru 
umetnosti, od škola i časopisa do pogleda posmatrača koji je, samim tim što određene načine delovanja prepoznaje kao umetničke, takođe, institucionalizovan.

Ako prihvatimo tezu da je institucionalna kritika od samih svojih početaka institucionalizovana, moglo bi se zaključiti da svaka kritika upućena institucijama neminovno inicira proces aproprijacije čiji je efekat, ne samo proširivanje institucionalnog polja delovanja, već i update samih institucija. Čini se da profitira sama institucija, jer dobija i auru "otvorenosti", opravdavajući ideju da mogućnost otpora postoji. Time se, istovremeno, ojačava legitimitet i integritet samih institucija. Da li je, onda, institucionalna kritika u funkciji, pre svega, institucija?

Moglo bi se zaključiti da jeste. Međutim, sve promene koje se dešavaju u umetnosti, vremenom dobijaju svoju institucionalnu formu, tako da se, po tom pitanju, institucionalna kritika ne razlikuje od drugih umetničkih pojava. Sama činjenica da se pojavljuje u trenutku kada su institucionalna teorija i kritika u krizi, umetničkim strategijama daje i širi diskurzivni okvir. Ono što je zajedničko za ove umetničke strategije je da problematizuju umetničke institucije i birokratski aparat kao tačke različitih interesnih sučeljavanja-ekonomskog, političkog, finansijskog -čime dovode u pitanje ideju autonomije kao ideološke pokrivalice za različite neumetničke interese.

To je, takođe, pokazalo da umetnost ne funkcioniše u strogo binarnom kodu-umetnost vs. ne-umetnost-što je dominantna logika 20. veka, modernističkog diskursa i čistih kategorija, već kao dispozitiv: polje u kojem se presecaju odnosi, moći i veze sa različitim registrima, umetničkim i neumetničkim. Pokazalo se, istovremeno, da odnosi moći nisu izvan umetnosti, izvan postojećih relacija u drugim registrima (ekonomskih, društvenih, političkih...), već su im imanentni. Sastavni deo iskustva institucionalne kritike je i to da u odnosu na moć ne postoji nezavisni položaj, po strani ili izvan, te samim tim ni određeno, jedno mesto otpora, što ujedno definiše razliku između prve i druge faze institucionalne kritike. Polazište u prvoj je da je mesto otpora izvan institucije, a u drugoj da su tačke otpora mnogostruke i unutar sistema.

Time su ocrtane unutrašnje granice kritičkog diskursa koji se zadržava na iskustvu umetničkih strategija prve faze institucionalne kritike, koji uračunava metapoziciju i mogućnost delovanja izvan. U tekstu "On Practice" (1975) Mel Ramsden zagovara izlaženje iz institucija i uvođenje zajednice kao novog frejminga umetničkog delovanja. Čini se da ovakav, sasvim sigurno, vrlo radikalni pristup ipak ostaje na nivou utopističkog projekta sa ne toliko precizno ocrtanim "novim" modelima delovanja. Drugim rečima, ostaje u recidivima mo- 13 dernističkog frejminga koji je, u tom trenutku, uveliko u krizi, jer ne pruža "alate" za razumevanje niza novih umetničkih praksi koje se pojavljuju. U Ramsdenovom tekstu to se prepoznaje i u insistiranju na ekskluzivnoj ulozi subjekta u odnosu na institucije i zadržavanju na dominantnoj dualnoj matrici, u ovom slučaju, subjekat vs. institucija. ${ }^{13}$ Sve što nije

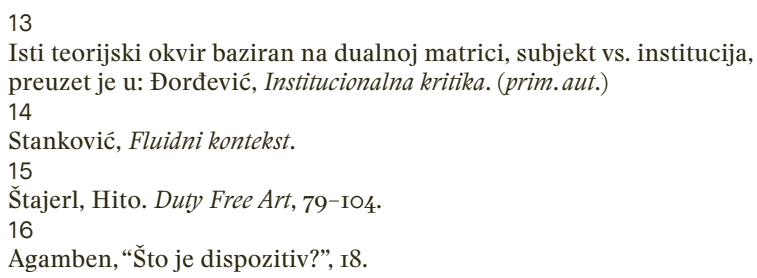


povezano sa subjektom ili u funkciji subjekta odbacuje se ili svodi na impersonalni sistem u kojem figurira birokratija. Iz istog razloga, on uvodi distancu i u odnosu na teoriju sistema, jer tu ne nalazi istaknutu i privilegovanu poziciju subjekta. S druge strane, teorija sistema je, čini se, bliska umetnicima na liniji konceptualnog iskustva i posebno umetnicima institucionalne kritike kao što je npr. Hans Haacke koji se direktno na nju poziva, kako bi se distancirao od ustaljene, ideološki obojene predstave autonomije.

Teorija sistema za polazište ima međudejstvo različitih sistema i kompatibilna je sa pojmom dispozitiva u filozofiji koji je ovde primenjen s ciljem da ocrta kako funkcioniše registar umetnosti. Ključni značaj institucionalne kritike je u tome što je, kroz različite umetničke strategije, ukazala na dispozitiv umetnosti: kao heterogeni sistem koji povezuje različita umetnička, ali i neumetnička kretanja, kao mrežu institucija, pojedinaca, infrastrukture, praksi, interesa i pojava. To, naravno, ne znači da je autonomija ukinuta-ona je uslov razlikovanja svakog od sistema-ali ono što, u mnogo većoj meri, konstituiše dispozitiv umetnosti su, pored umetničkih, i različita kretanja koja dolaze iz drugih registara: ekonomskog, političkog, finansijskog... Iz toga se može zaključiti da su prakse institucionalne kritike kompatibilne sa, u tom trenutku, najaktuelnijim teorijskim, ali i naučnim uvidima, imajući u vidu da je teorija sistema neodvojiva od pojave niza novih nauka kao što su informatika, kibernetika, teorija komunikacija i sl.

Međuzavisnost različitih sistema u dispozitivu umetnosti na koje je ukazalo iskustvo institucionalne kritike je, istovremeno, preduslov za razumevanje savremene umetnosti. To je, ujedno, i razlog zašto se i na početku 21. veka govori o novim talasima institucionalne kritike. Čini se, ipak, da nisu u pitanju novi talasi institucionalne kritike, već da je to iskustvo sastavni deo umetnosti do danas bez kojeg nema savremenog mišljenja (u) umetnosti. To, pre svega, znači da kritička recepcija aktuelnog dispozitiva umetnosti uračunava umreženi način funkcionisanja koji nije u u suprotnosti sa autonomijom. Autonomija je dostignuti istorijski lejer, pretpostavka umetnosti kao zasebnog društvenog registra. Ono što je, međutim, od konstitutivnog značaja za dispozitiv umetnosti je niz procesa, umetničkih i neumetničkih, koji se ukrštaju, prepliću i u zavisnosti od intenziteta konstituišu dominantna kretanja u umetnosti.

Ako je veći deo 20. veka obeležila dominacija muzeja u dispozitivu umetnosti i kritika istog, koja se konstiuiše kroz prakse institucionalne kritike, kretanja na početku 21. veka neodvojiva su od dominantne paradigme neoliberalnog kapitalizma i s tim povezane tržišne logike. Tržište nije samo mesto razmene, kretanja kapitala, već i tačka koja je konstitutivna za produkovanje umetničkog rada na šta ukazuje, simbolično i doslovno u isto vreme, Banksyjev rad Love is in the Bin (2018.). Na to upućuje i niz pojava koje se, gotovo u jednakim vremenskim razmacima pojavljuju, od osamdesetih godina, kada kreće dominacija tržišta, do danas, a čije je zajedničko polazište vraćanje slici, koja, opet do danas, zauzima dominantno mesto na tržištu. Na ovoj liniji pojavljuje se i tzv. postsavremena ili postdigitalna umetnost, koja se prezentuje kao najnoviji "trend" u umetnosti, a zapravo je istrošeni, konvencionalni i konzervativni način mišljena (u) umetnosti.

Muzeji se, s druge strane, nalaze u nezavidnom položaju. Prvo, nemaju više ekskluzivnu ulogu u prezentovanju umetnosti, jer kontekst kao dominantna i promenljiva komponenta umetničkog rada definiše razliku između umetničkog i neumetničkog, a ne fizički prostor institucije u kojem se izlaže. ${ }^{14}$ Pored toga, "u rascepu" su između modernističkog i neoliberalnog modela: i dalje imaju privilegovanu poziciju, jer su pod okriljem države, ali ne i centralnu iako u nju "veruju". Štaviše, ukoliko nisu povezani sa produkcijom - umetničkom, kritičkom i teorijskom-i drugim akterima u mreži, njihova pozicija irelevantna je i svedena na opsluživanje birokratskog aparata. Ono što je posebno indikativno, kao ključna razlika u odnosu na 20. vek i dispozitiv modernosti je što su izgubili svoju identitetsku funkciju. To najbolje ocrtava sintagma koju uvodi Steyerl: duty free art, u doslovnom prevodu, "umetnost bez obaveza/dužnosti". ${ }^{15}$ To je umetnost koja je izgubila sve svoje nasleđene uloge kao nacionalnog, kulturnog dobra i vrednosti po sebi, što se u velikoj meri može primeniti i na muzeje.

Proces gubljenja identitetskih funkcija može se posmatrati i u širem okviru, koje Agamben naziva fazama subjektivacije i desubjektivacije. Prva je povezana sa tradicionalnim dispozitivom (kraj 18. veka, početak dominacije kapitalizma) u kojoj je dispozitiv "stroj koji proizvodi subjektivacije". ${ }^{16}$ To se može dovesti u vezu sa Foucaultovom analizom disciplinarnog društva u kojoj se pominju brojni primeri subjektivacije koji su efekat povlačenja granice između normalnog i devijantnog (zatvorenik, bolesnik, delikvent, perverznjak, histerična žena...). U sadašnjoj fazi kapitalizma, subjektivacija je, kako navodi Agamben samo jedna od faza u procesu desubjektivizacije. U posthumanističkom, biopolitičkom društvu subjekt je jedinica biomase, dok su identiteti prolazni i promenljivi i u funkciji biopolitičkih strategija. Na to posebno ukazuje eskalacija identitetskih određenja koja svoj zenit dostiže devedesetih godina prošlog veka uvođenjem gay, drag i queer kulture. Ovaj proces je doveo do uvođenja kulturnih razlika i, s njima povezanih, mnogobrojnih emancipacijskih praksi. U stopu ga je, međutim, pratio i proces, u tom trenutku, ne sasvim vidljiv, a to je uvođenje tržišne logike koja je dobijala sve dominantniju ulogu u dispozitivu umetnosti.

Jedan od novijih radova koji direktno problematizuje dominaciju tržišne logike u savremenoj umetnosti je rad Maurizija Cattelana Comedian (2019.). Rad se pojavio na sajmu Art Basel u Miami Beachu i sastoji se od banane zalepljene lepljivom trakom na zidu. Cena rada je 120000 \$, odmah je prodat, tako da je ubrzo dobio i svoju drugu, a zatim i treću ediciju, naravno, po uvećanoj ceni. Odmah nakon toga pojavio se niz članaka koji su, polazeći manje-više od sličnih pretpostavki imali jedno zajedničko pitanje, a to je: da li je 
moguće da je banana danas umetnost? Da li je to šala dotičnog umetnika prepoznatljivog po svom smislu za humor ili pak upućuje na ozbiljnu krizu u umetnosti? Pojavio se i niz argumenata kojim su podržane obe teze. Ipak, ono što je simptomatično jeste da gotovo svi argumenti polaze od iste stvari: banane! Svi imaju isto polazište, a to je svođenje rada na jednu komponentu, materijalnu. Banana, naravno, nije umetničko delo; čak i da je genetski modifikovana, to joj još uvek ne daje artificijelni status. Ovakvoj "zdravorazumskoj" argumentaciji (kako banana može da bude umetničko delo?), koja polazi od formalne, materijalne komponente i tu se zaustavlja, izmiče nešto drugo, a to je svođenje umetničkog rada na tržišni predmet, što je dominantna logika kapitala na koju Cattelan ovim radom cinično ukazuje, a njegov galerista izgovara: "If you don't sell the work, it's not a work of art". ${ }^{17}$ 


\section{POPIS LITERATURE / BIBLIOGRAPHY}

Agamben, Đorđo. "Što je dispozitiv?" (preveo Mario Kopić). Beograd: FMK, 2019.

Alberro, Alexander, Stimson, Blake (ur.). Institutional Critique. MIT: 2009.

Bauman, Zigmunt. Fluidni život. Novi Sad: Mediterran Publishing, 2009.

Birger, Peter. Teorija avangarde, Beograd: Narodna knjiga-Alfa, 1998.

Bois, Yve-Alain, Buchloh, Benjamin, Joselit, David, Foster, Hal, Krauss, Rosalind. Art Since 1900. Thames \& Hudson: 2005.

Buhloh, Benjamin. "Od estetike administracije do kritike institucija", Prelom, br. 8/9, Beograd: Prelom kolektiv, 2008.

Cascone, Sarah. "Maurizio Cattelan Is Taping Bananas to a Wall at Art Basel Miami Beach and Selling Them for $\$ 120,000$ Each". Artnet News: https://news.artnet.com/market/ maurizio-cattelan-banana-art-basel-miami-beach-1722516 (pristupljeno 5.12.2019).

Đorđević, Marko. Institucionalna kritika. Beograd: FMK-Orion Art, 2015.

Frejzer, Andrea. "Od kritike institucija do institucije kritike", Prelom, 8/9, Beograd: Prelom kolektiv, 2008.

Greenberg, Klement. "Modernističko slikarstvo", 3+4, (prevela Nada Seferović). Beograd: 1978.

Grejber, Dejvid. Utopija pravila. Beograd: Geopoetika, 2016.

Ramsden, Mel. "On Practice" (1975.), 905-908. U: Art in Theory 1900-1990. An Anthology of Changing Ideas, ur. Charles Harrison i Paul Wood. Cambridge Mass.: Blackwell Publishers, 1994.

Stanković, Maja. Fluidni kontekst. Kontekstualne prakse u savremenoj umetnosti. Beograd: FMK, 2015.

Šeik, Sajmon. "Beleške o institucionalnoj kritici", Prelom, br. 8-9, Beograd: Prelom kolektiv, 2008.

Štajerl, Hito. Duty Free Art. Beograd: FMK, 2019. 